\title{
PHYSIOLOGICAL RESPONSES TO INSULIN HYPOGLYCAEMIA IN SPINAL MAN
}

\author{
By C. J. Mathias, ${ }^{1}$ D.Phil., M.R.C.P., H. L. Frankel, M.B., F.R.C.P., \\ R. C. Turner, M.D., F.R.C.P. and N. J. Christensen, ${ }^{2}$ M.D. \\ National Spinal Injuries Centre, Stoke Mandeville Hospital, Aylesbury; Department of \\ Neurology, Churchill Hospital and Nuffield Department of Medicine, Radcliffe Infirmary, \\ Oxford; and Second Clinic of Internal Medicine, Kommunehospitalet, Aarhus, Denmark
}

Summary. The physiological responses to hypoglycaemia induced by fish insulin were studied in nine tetraplegic subjects with physiologically complete cervical spinal cord transection between $\mathrm{C}_{4}$ and $\mathrm{C} 8$. During hypoglycaemia there was a reduction in both systolic and diastolic blood pressure unlike in normal subjects. This was accompanied by a rise in heart rate. The normal rise in plasma adrenaline levels did not occur. Plasma human insulin levels were suppressed. The usual neuroglycopenic symptoms accompanying hypoglycaemia did not occur in the tetraplegics.

Key words: Tetraplegia; Insulin; Hypoglycaemia; Catecholamines.

\section{Introduction}

IN normal man insulin hypoglycaemia results in a rise in systolic blood pressure, a fall in diastolic blood pressure and a tachycardia (Lloyd-Mostyn \& Oram, 1975). There is a marked rise in plasma adrenaline levels (Christensen et al., 1975) and a marked decrease in plasma human insulin levels (Turner \& Johnson, 1973). Symptoms such as a sense of vague ill-health, anxiety, panic, hunger, palpitations and restlessness accompany hypoglycaemia in normal man (Marks \& Rose, 1965). In man the relationship of these responses to sympathetic activity is not clearly known. To elucidate this further we studied the responses to insulin-induced hypoglycaemia in tetraplegics with complete cervical spinal cord transection as in these subjects there is no connection between the brain and the peripheral sympathetic nervous system. In our study arterial blood pressure and heart rate were recorded continuously and plasma glucose, noradrenaline, adrenaline and human insulin were measured at intervals before and after the administration of insulin. Fish insulin was administered to induce hypoglycaemia as it enabled measurement of endogenous (human) insulin with the use of a specific antiserum (Turner \& Johnson, 1973).

\section{Patients}

Nine tetraplegic subjects (eight male and one female) with physiologically complete cervical spinal cord transections between $\mathrm{C}_{4}$ and $\mathrm{C} 8$ were studied. None had motor or sensory function below the segmental level of the lesion. The subjects were aged between $2 \mathrm{I}$ and 43 years. All were in good health and 36 hours prior to the study all drugs were withdrawn. Informed consent was obtained from

1 Medical Unit, St. Mary's Hospital Medical School, London.

2 Department of Internal Medicine and Endocrinology, Herley Hospital, Denmark. 
each and the methods used were approved by the Ethics of Research Committee of Stoke Mandeville Hospital.

\section{Methods}

All subjects were studied while supine and after an overnight fast. Blood pressure was measured, using previously described techniques, from an intraarterial cannula introduced percutaneously (Mathias et al., 1975; Mathias, 1976). Heart rate was obtained from the arterial pressure signal. The electrocardiograph was monitored continuously and occasionally recorded. A venous cannula was inserted into a forearm vein for withdrawal of blood for plasma glucose and plasma human insulin measurements. Plasma glucose was measured using glucose oxidase (Boehringer kit) and plasma human insulin using charcoal phase separation (Turner \& Johnson, 1973). Plasma noradrenaline and adrenaline in arterial blood were measured using a double isotope derivative technique (Christensen, I973).

In six tetraplegic subjects fish insulin was administered as a single intravenous injection (O.I to O.I5 units/kg body weight). Venous blood samples for measurement of plasma glucose and human insulin were taken at IO-min intervals before and after injection for a total of I $80 \mathrm{~min}$. Arterial blood samples were taken before and $15,30,45$ and 60 min after injection for measurement of plasma noradrenaline and adrenaline. In three tetraplegic subjects fish insulin was administered intramuscularly ( 0.2 units $/ \mathrm{kg}$ body weight) at 0,45 and $90 \mathrm{~min}$. At the end of each study the subjects were given $50 \mathrm{ml}$ of 50 per cent glucose intravenously. Control data for comparison was obtained from I 3 normal subjects studied under similar conditions, except that in the study using intravenous insulin 0.2 units $/ \mathrm{kg}$ body weight was administered (Turner \& Johnson, 1973; Christensen et al., 1975).

\section{Results}

In the tetraplegics intravenous insulin resulted in a fall in plasma glucose levels which was maximal after $30 \mathrm{~min}$. Basal levels of systolic, diastolic and mean blood pressure were subnormal in the tetraplegics; this is in keeping with previous observations (Mathias et al., 1976a). There was a progressive fall in both systolic and diastolic blood pressure with increasing hypoglycaemia (Table I) $(\mathrm{P}<0.0 \mathrm{I}$ and $<0.05$ respectively at $30 \mathrm{~min}$.) Heart rate rose significantly as blood pressure fell $(\mathrm{P}<0.05$ respectively at $30 \mathrm{~min}$.

In the tetraplegics hypoglycaemia was not accompanied by a change in either plasma adrenaline or noradrenaline levels (Table II and Fig. I). Basal levels of plasma adrenaline and noradrenaline were low, as observed previously (Mathias

\section{TABle I}

Average levels \pm SEM of glucose $(\mathrm{mg} / \mathrm{IOO} \mathrm{ml})$, systolic, diastolic and mean blood pressure $(\mathrm{BP}, \mathrm{mm} \mathrm{Hg}$ ) and heart rate (beats/min) in six tetraplegics before (o) and I 5, 30, 45 and $60 \mathrm{~min}$ after intravenous fish insulin ( $0.1-0.15 \mathrm{units} / \mathrm{kg}$ body weight).

\begin{tabular}{ccrccc}
\hline Time & Glucose & Systolic BP & Diastolic BP & Mean BP & Heart rate \\
\hline o & $79 \pm$ I.5 & II $\pm \pm 5 \cdot 0$ & $57 \pm 4 \cdot 9$ & $76 \pm 4 \cdot 9$ & $62 \pm 3 \cdot 5$ \\
I5 & $59 \pm 2 \cdot 4$ & I07 $\pm 8 \cdot 2$ & $53 \pm 3 \cdot 8$ & $72 \pm 5 \cdot 4$ & $67 \pm 3 \cdot 8$ \\
30 & $39 \pm 3 \cdot 5$ & $99 \pm 8 \cdot 7$ & $52 \pm 4 \cdot 4$ & $67 \pm 4 \cdot 9$ & $69 \pm 2 \cdot 2$ \\
45 & $43 \pm 3 \cdot 0$ & I02 $\pm 9 \cdot 4$ & $54 \pm 4 \cdot 7$ & $70 \pm 6 \cdot 3$ & $72 \pm 2 \cdot 1$ \\
60 & $48 \pm 2 \cdot 9$ & I04 $\pm 5 \cdot 7$ & $53 \pm 2 \cdot 3$ & $70 \pm 3 \cdot 2$ & $70 \pm 4 \cdot 1$ \\
\hline
\end{tabular}


TABLE II

Average levels \pm SEM of glucose $(\mathrm{mgm} / \mathrm{IO0} \mathrm{ml}$ ), noradrenaline and adrenaline $(\mathrm{ng} / \mathrm{ml})$ in six tetraplegics $(\mathrm{T})$ and six controls (C) before (o) and I 5, 30, 45 and $60 \mathrm{~min}$ after intravenous insulin (0.I-0.2 units $/ \mathrm{kg}$ body weight).

\begin{tabular}{|c|c|c|c|c|c|c|}
\hline \multirow[t]{2}{*}{ Time } & \multicolumn{2}{|c|}{ Glucose } & \multicolumn{2}{|c|}{ Noradrenaline } & \multicolumn{2}{|c|}{ Adrenaline } \\
\hline & $\mathrm{T}$ & $\mathrm{C}$ & $\mathrm{T}$ & $\mathrm{C}$ & $\mathrm{T}$ & $\mathrm{C}$ \\
\hline 0 & $79 \pm \mathrm{I} \cdot 5$ & $70 \pm I \cdot 9$ & $0.10 \pm 0.034$ & $0.25 \pm 0.053$ & $0.02 \pm 0.013$ & $0.05 \pm 0.026$ \\
\hline I5 & $59 \pm 2 \cdot 4$ & $42 \pm 3 \cdot 0$ & $0.10 \pm 0.037$ & $0.23 \pm 0.040$ & $0.02 \pm 0.013$ & $0.02 \pm 0.000$ \\
\hline 30 & $39 \pm 3 \cdot 5$ & $23 \pm I \cdot 9$ & $0.1 I \pm 0.029$ & $0.31 \pm 0.0$ & $0.02 \pm 0.013$ & $0.32 \pm 0.207$ \\
\hline 45 & $43 \pm 3 \cdot 0$ & $30 \pm 3$ & $0.09 \pm 0.055$ & $0.48 \pm 0.080$ & $0.01 \pm 0.000$ & $0.97 \pm 0.185$ \\
\hline 60 & $48 \pm 2 \cdot 9$ & $34 \pm I \cdot 9$ & $0.12 \pm 0.029$ & $0.38 \pm 0.080$ & $0.02 \pm 0.013$ & $0.64 \pm 0.124$ \\
\hline
\end{tabular}

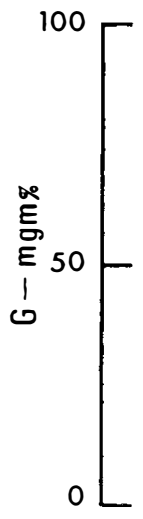

Tetraplegics

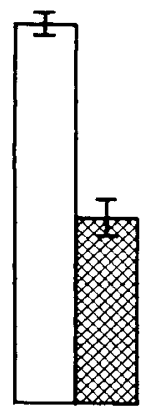

G

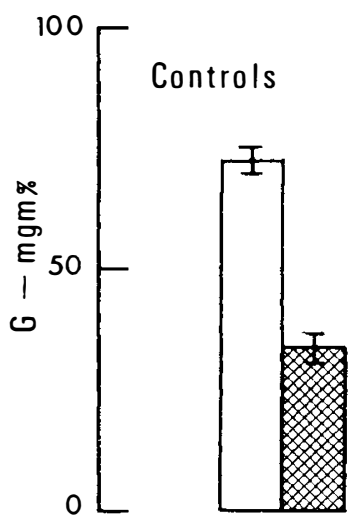

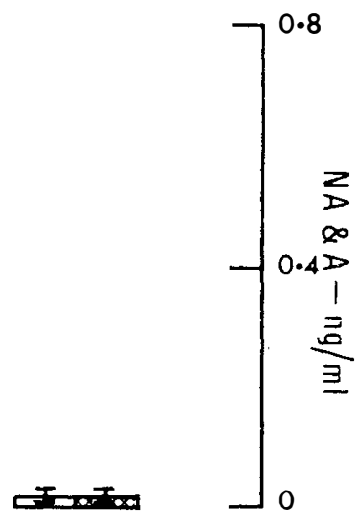

A

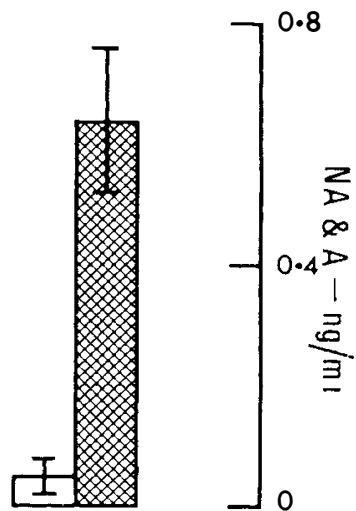

FIG. I

Comparison of mean levels of plasma noradrenaline (NA) and adrenaline (A), in six tetraplegic subjects and six control subjects before (blank histograms) and during (shaded histograms) comparable levels of insulin-induced hypoglycaemia. Mean plasma glucose levels (G) are included. Vertical lines indicate \pm SEM. 
et al., I976a). In the controls there was a marked rise in plasma adrenaline levels. Plasma noradrenaline also rose significantly $(P<0 \cdot 00 \mathrm{I})$.

In the normal subjects there was a close relationship between plasma glucose and plasma human insulin levels. Plasma human insulin levels fell by $32 \pm 7$ per cent for a $10 \mathrm{mg} / 100 \mathrm{ml}$ fall in plasma glucose; the human insulin level was also less than $\mathrm{I} \cdot 5$ units $/ \mathrm{ml}$ when plasma glucose was less than $35 \mathrm{mg} / \mathrm{I00} \mathrm{ml}$. In the tetraplegics in the study using intravenous fish insulin there was suppression of plasma human insulin with the fall in plasma glucose (Fig. 2). However, in two tetraplegic subjects basal levels of human insulin were high, and although suppression occurred during hypoglycaemia the lowest levels of human insulin were 3.3 and 4.5 units $/ \mathrm{ml}$. In the three tetraplegics in whom fish insulin was ad-

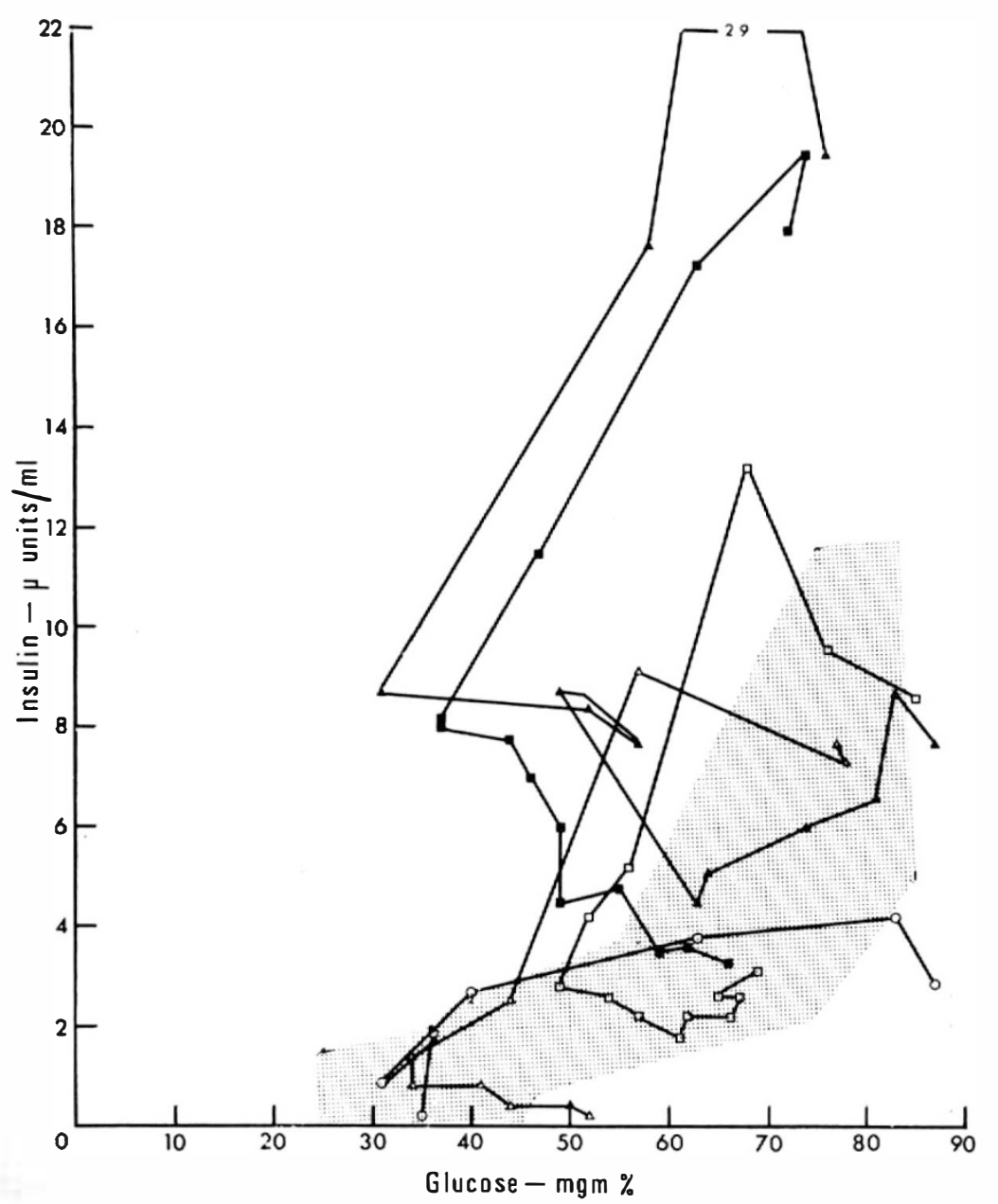

FIG. 2

Relationship of plasma human insulin to plasma glucose in five tetraplegic subjects during fish insulin-induced hypoglycaemia. The shaded area indicates limits of values from normal subjects during intramuscular insulin-induced hypoglycaemia (Turner \& Johnson, 1973). In Tetraplegics intravenous insulin induced suppression similar to that seen in normal subjects (Turner 1976) except that the plasma insulin level fell to below $2 \mu$ units $/ \mathrm{ml}$ in all normal subjects. 
ministered intramuscularly human insulin levels were, as in normal subjects, suppressed with hypoglycaemia (Fig. 3). Mean levels of human insulin were, however, higher in the tetraplegics.

In the tetraplegics the usual symptoms accompanying hypoglycaemia did not occur. Most subjects felt drowsy and lapsed into a light sleep. This was reversed at the end of the study by intravenous glucose.
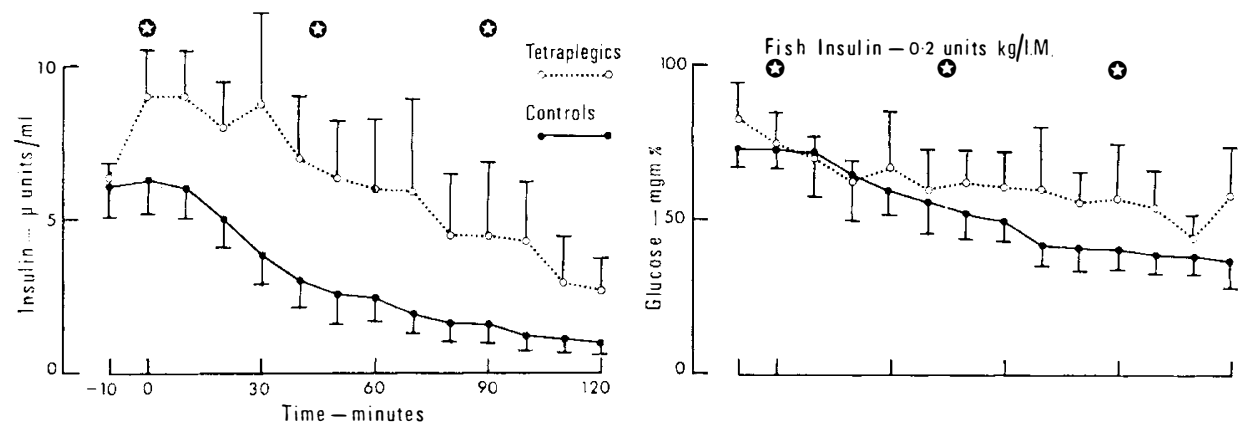

FIG. 3

Mean levels of plasma glucose and plasma human insulin following repeated intramuscular injections (indicated by an asterisk) of 0.2 units $/ \mathrm{kg}$ of fish insulin in three tetraplegic and seven normal subjects. The vertical lines indicate \pm SEM.

\section{Discussion}

It has been suggested that in normal subjects the cardiovascular changes accompanying hypoglycaemia are the result of increased sympathetic activity and release of adrenaline into the circulation. Adrenalectomised subjects and patients given the ganglion blocker hexamethionium do not exhibit the normal cardiovascular changes during hypoglycaemia (Ginsburg \& Paton, I956; Di Salvo et al., 1956) and it may be argued that this lends some support to this hypothesis. In patients with autonomic neuropathy insulin hypoglycaemia has been reported to cause a fall in both systolic and diastolic blood pressure (Luft \& von Euler, I953). Similar changes have also been reported in diabetics with autonomic neuropathy (Page \& Watkins, 1976). In the tetraplegic subjects insulin hypoglycaemia resulted in a fall in both systolic and diastolic blood pressure. Insulin decreases intravascular volume, and in subjects with normal autonomic function this increases adrenergic activity (Gundersen \& Christensen, 1977). In the tetraplegics, however, although the afferent limb of the baroreceptor arc is intact the sympathetic component of the efferent limb in the cervical spinal cord is disrupted by the lesion. This results in their inability to reflexly increase sympathetic nervous activity and may account for the observed fall in blood pressure during a decrease in intravascular volume. The role of vasodilatation induced either by hormones or nerves in response to insulin hypoglycaemia in these subjects is also not clearly known. This may be of relevance as the compensatory mechanisms to counteract this are impaired in these subjects.

The tachycardia occurring during hypoglycaemia in normal subjects is thought by some workers to be unrelated to circulating levels of plasma adrenaline (Christensen et al., 1975). In patients in whom splanchnicectomy has been performed and in whom the sympathetic nerves from $\mathrm{T}_{7}$ and below have been removed, there is a rise in heart rate during insulin hypoglycaemia (French \& 
Kilpatrick, I955). In these subjects urinary excretion of adrenaline during hypoglycaemia does not increase. In our normal subjects there was a rise in plasma noradrenaline levels during hypoglycaemia and this suggests an increase in sympathetic nervous activity. In the subjects studied by French and Kilpatrick as the denervation was from $\mathrm{T}_{7}$ and below the sympathetic fibres to the heart would have been intact. It is likely that the tachycardia occurring during hypoglycaemia in these subjects resulted from increased activity in cardiac sympathetic nerves. In the tetraplegics the small rise in heart rate which occurred during hypoglycaemia was probably a baroreceptor induced reflex mediated by a withdrawal of vagal cardiac tone in response to the fall in blood pressure. This may have also contributed to the rise in heart rate in the subjects studied by French and Kilpatrick as they too observed a fall in systolic and diastolic blood pressure during hypoglycaemia.

In normal subjects insulin hypoglycaemia is accompanied by a marked increase in plasma adrenaline levels (Goldfein et al., I96I; Christensen et al., 1975). A twofold rise in plasma noradrenaline also occurs. No such changes occurred in the tetraplegic subjects during hypoglycaemia. This is an indication of the inability of tetraplegics to increase sympathetic activity during hypoglycaemia. In the tetraplegics, however, the lack of response was not a result of atrophy or destruction of sympathetic nerve endings but reflects an inability to reflexly activate them. In these subjects sympathetic reflex arcs at a spinal level can be activated by stimuli from the skin, viscera or skeletal muscles (Corbett et al., I97I $a, b$ and 1975). These stimuli result in increased sympathetic nervous activity which is characterised by a rise in blood pressure. Plasma noradrenaline and dopamine beta-hydroxylase, both of which are thought to be markers of sympathetic nervous activity, rise during such stimulation (Mathias et al., I976a, $b$ ). The absence of a rise in either plasma noradrenaline or adrenaline levels in response to hypoglycaemia suggests that the centres in the brain which coordinate sympathetic activity in response to hypoglycaemia have pathways which descend through the cervical spinal cord.

The mechanisms involved in suppression and release of insulin are complex. There is evidence in normal man that insulin responses are mediated by specific pancreatic glucose receptors (Robertson \& Porte, I973). However, alpha adrenergic agonists inhibit insulin release while alpha adrenergic blockade stimulates insulin release (Iversen, I973; Burns et al., 1974). Furthermore, beta adrenergic agonists such as isoprenaline increase insulin release while beta adrenergic blockers such as propranolol reduce insulin release (Deckert et al., 1972; Cerasi et al., 1969). In the tetraplegics the intravenous administration of fish insulin resulted in hypoglycaemia and suppression of endogenous human insulin levels. The pattern of fall was similar to that seen in response to intravenous insulin in normal subjects (Turner, 1976). Two tetraplegics had high basal levels which only fell to 3.3 and $4 \mu$ units $/ \mathrm{ml}$. and both subjects were obese. This may have also accounted for the higher mean insulin levels recorded in the intramuscular fish insulin study, during which there appeared to be marginally less insulin suppression than in normal subjects. These observations are of interest as alpha adrenergic blockade in normal subjects slightly impairs the suppression of insulin secretion in response to induced hypoglycaemia (Turner, Hart and London, 1977). The overall results, however, suggest that suppression of insulin secretion is more dependant upon plasma glucose concentration than upon the sympathetic nervous system.

The neuroglycopenic symptoms accompanying hypoglycaemia were conspicuously absent in the tetraplegic subjects. The absence of the warning signs 
accompanying hypoglycaemia are of clinical importance in this group of subjects. The combination of an impaired locomotor state and a lack of awareness of hypoglycaemia could therefore cause these subjects to be at greater risk from the metabolic and neurological derangements which result from hypoglycaemia.

\section{RÉSUMÉ}

Les auteurs ont étudié chez 9 tétraplégiques complets avec lésion médullaire entre $\mathrm{C}_{4}$ and $\mathrm{C} 8$ les réponses cardiovasculaires et hormonales à l'hypoglycémie provoquée par l'insuline de poisson. Durant l'hypoglycémie au contraire des sujets normaux, on observe une diminution des pressions systoliques et diastoliques, avec augmentation concomitante du rythme cardiaque sans avoir l'élévation habituelle d'adrénaline dans le sang. Il y eut également une diminution des niveaux de l'insuline humaine. Chez le tétraplégique on ne trouve pas la symptomatologie nerveuse habituelle qui accompagne l'hypoglycémie.

\section{ZUSAMMENFASSUNG}

Die Reaktionen des Herzkreislaufsytems und die Reagierung im Hormonen Bereich nach Gabe von Fisch-Insolin werden bei neun vollständigen Halsmarkgelähmten untersucht. Während der HYPOGLYKAEMIE bestand eine Blutdrucksenkung sowohl systolische als auch diastolische. Eine vergleichbare Blutdrucksenkung besteht nicht bei Gesunden. Gleichzeitig kam es zu einer Pulsverschnellung. Es kam nicht zu einer normalen Steigung des Plasma-Adrenalin. Das menschliche Plasma-Insulin war nicht erniedrigt. Die sonst üblichen Symptome wahrend einer HyPOGLYKAEMIE, besondere neurologische Zeichen, wurden bei Halsmarkgelähmten nicht beobachtet.

Acknowledgements. We wish to thank Miss E. Harris, Mrs Pamela Smith and Sisters Mary Brennan and Eleanor Kidd for their help during the study and Miss Pamela Andrews for secretarial assistance. During the study C. J. M. was a Rhodes Scholar at the University of Oxford and a Research Fellow of the National Spinal Injuries Centre. The support of the Lawson Tait Medical and Scientific Research Trust is gratefully acknowledged.

\section{REFERENCES}

Burns, T. W., Mohs, J. M., Langley, P. E., Yawn, R. \& Chase, G. R. (1974). Regulation of human lipolysis. In vivo observations on the role of adrenergic receptors. Fournal of Clinical Investigation, 53, 338-34I.

Cerasi, E., EFFENDIC, S. \& LUFT, R. (I969). Role of adrenergic receptors in glucoseinduced insulin secretion in man. Lancet, ii, 301-302.

Christensen, N. J. (1973). Plasma noradrenaline and adrenaline in patients with thyrotoxicosis and myxoedema. Clinical Science and Molecular Medicine, 45, I63-I71.

Christensen, N. J., Alberti, K. G. M. M. \& Brandsborg, O. (I975). Plasma catecholamines and blood substrate concentrations: studies in insulin-induced hypoglycaemia and after adrenaline infusions. European fournal of Clinical Investigation, 5, 415-423.

CorbetT, J. L., Frankel, H. L. \& HARRIS, B. J. (I 97I $a$ ). Cardiovascular changes associated with skeletal muscle spasm in tetraplegic man. Fournal of Physiology (London), 215, $38 \mathrm{I}-393$.

Corbett, J. L., Frankel, H. L. \& Harris, B. J. (I971b). Cardiovascular reflex responses to cutaneous and visceral stimuli in spinal man. Fournal of Physiology (London), 215, 395-409.

Corbett, J. L., Debarge, O., Frankel, H. L. \& Mathias, C. J. (1975). Cardiovascular responses in tetraplegic man to muscle spasm, bladder percussion and head uptilt. Clinical and Experimental Pharmacology and Physiology, 2, Suppl. II, I89-193.

Deckert, R., Lauridsen, U. P., Madsen, S. N. \& Deckert, M. (I972). Serum insulin following isoprenaline in normal and diabetic persons. Hormonal and Metabolic Research, 4, 229-232.

Di Salvo, R. J., Bloom, W. L., Brust, A. A., Ferguson, R. W. \& Ferris, E. B. (I976). A comparison of the metabolic and circulatory effects of epinephrine, norepinephrine, and insulin hypoglycaemia with observations on the influence of autonomic blocking agents. Fournal of Clinical Investigation, 35, 568-577. 
FRENCH, E. B. \& KILPATRICK, R. (I955). The role of adrenaline in hypoglycaemic reactions in man. Clinical Science, 14, 639-65I.

Ginsburg, G. \& Paton, A. (I956). Effects of insulin after adrenalectomy. Lancet, ii, 49I-494.

Goldfien, A., Moore, R., Zilelis, Havens, L. L., Boling, L. \& Thorn, G. W. (I96I). Plasma epinephrine and norepinephrine levels during insulin-induced hypoglycaemia in man. Fournal of Clinical Endocrinology, 21, 296-304.

GuNDERSEN, H. J. G. \& CHRISTENSEN, N. J. (I977). Intravenous insulin causing loss of intravascular water and albumin and increased adrenergic nervous activity in diabetics. Diabetes, 26, 55I-557.

IVERSEN, J. (I973). Adrenergic receptors and the secretion of glucagon and insulin in the isolated, perfused canine pancreas. Fournal of Clinical Investigation, 52, 2102-21 16.

LLOYD-MOSTYN, R. H. \& ORAM, S. (I975). Modification by propranolol of cardiovascular effects of induced hypoglycaemia. Lancet, i, I213-1215.

LUfT, R. \& vON EULER, U. S. (I953). Two cases of postural hypotension showing a deficiency in release of norepinephrine and epinephrine. Fournal of Clinical Investigation, 32, $1065-1069$.

Marks, V. and Rose, F. C. (1965). Hypoglycaemia. Blackwell Scientific Publications, Oxford.

Mathias, C. J. \& Christensen, N. J., Corbett, J. L., Frankel, H. L., Goodwin, D. J. \& PeART, W. S. (1975). Plasma catecholamines, plasma renin activity and plasma aldosterone in tetraplegic man, horizontal and tilted. Clinical Science and Molecular Medicine, 49, 291-299.

Mathias, C. J. (1976). Neurological Disturbances of the Cardiovascular System. Doctor of Philosophy Thesis, University of Oxford.

Mathias, C. J., Christensen, N. J., Corbett, J. L., Frankel, H. L. \& Spalding, J. M. K. (1976a). Plasma catecholamines during paroxysmal neurogenic hypertension in quadriplegic man. Circulation Research 39, 204-208.

Mathias, C. J., Smith, A. D., Frankel, H. L. \& Spalding, J. M. K. (I976b). Release of dopamine beta hydroxylase during hypertension from sympathetic overactivity in man. Cardiovascular Research, 10, I76-181.

Page, M. McB. \& Watkins, B. J. (1976). Provocation of postural hypotension by insulin in diabetic autonomic neuropathy. Diabetes, 25, 90-95.

Robertson, R. P. \& Porte, D. (1973). The glucose receptor. A defective mechanism in diabetes mellitus distinct from the beta adrenergic receptor. Fournal of Clinical Investigation, $\mathbf{5 2}, 870-876$.

Turner, R. C. \& Johnson, P. C. (1973). Suppression of insulin release by fish insulininduced hypoglycaemia with reference to the diagnosis of insulinomas. Lancet, $\mathbf{i}$, I $483-1485$.

TURNER, R. C. (1976). The diagnosis of insulinomas and other causes of fasting hypoglycaemia. Hypoglycaemia: Proceedings of the European Symposium, Rome. Editors: R. Levine and E. F. Pfeiffer. Supplement Series, Vol. No. 6, George Thieme, Publishers Stuttgart, 40-45.

TURNER, R. C., HART G., \&LONDON, D. R. (1977). Suppression of basal insulin secretion by adrenalin in normal man and in patients with insulinomas. Diabetologia, 13, 19-23. 